\title{
Adrenal glands of Spix's yellow-toothed cavy (Galea spixii, Wagler, 1831): morphological and morphometric aspects
}

\author{
A. C. Santos ${ }^{a *}$, D. C. Viana ${ }^{a}$, B. M. Bertassoli, B. G. Vasconcelos ${ }^{c}$, D. M. Oliveira ${ }^{a}$, \\ R. E. G. Rici ${ }^{a}$, M. F. Oliveira ${ }^{d}$, M. A. Miglino ${ }^{a}$ and A. C. Assis-Neto ${ }^{a}$
}

aPost Graduate Program Anatomy of Domestic and Wild Animals, Department of Surgery, School of Veterinary Medicine and Animal Science, Universidade de São Paulo - USP, Av. Prof. Dr. Orlando Marques de Paiva, 87,

CEP 05508-270, São Paulo, SP, Brazil

bPost Graduate Program of Cellular Biology, Department of Morphology, Universidade Federal de Minas Gerais - UFMG, Av. Presidente Antônio Carlos, 6627, CEP 31270-901, Belo Horizonte, MG, Brazil

'Sector Animal Anatomy, Institute of Health Sciences, Universidade Federal do Mato Grosso - UFMT, Campus Sinop,

Av. Alexandre Ferronato, 1200, Setor Industrial, CEP 78557-267, Sinop, MT, Brazil

dPost Graduate Program of Animal Science, Department of Animal Science, Universidade Federal Rural do Semi-Árido - UFERSA, Rodovia BR 110, Km 47, CEP 59625-900, Mossoró, RN, Brazil

*e-mail: amiltonsantoss@bol.com.br

Received: November 12, 2014 - Accepted: April 28, 2015 - Distributed: August 31, 2016

(With 7 figures)

\begin{abstract}
Considering the physiological importance and need of greater morphophysiological knowledge of adrenal glands, the aims of present study were compare the morphometric data between left and right adrenal of male and female; perform a histological, scanning and transmission electron microscopy study showing tissue constitution of glands; finally, in order to define the presence and correct site of the cytochrome P450c17 expression in adrenal glands, immunohistochemical study of this enzyme was performed in 18 adrenal glands (right $\mathrm{n}=9$ and left $\mathrm{n}=9$ ) of nine adult Galea spixii (four males and five females). Right adrenal was more cranially positioned than left adrenal; dimensions (weight, length and width) of right adrenal was larger than left adrenal; no differences between male and female body and adrenal measurements were found; the morphology of cells and different amounts of lipid droplets may be related to the different demands of steroid hormones production, related to each zone of the adrenal cortex; and, the cytochrome P450c17 immunolocalization in fasciculate and reticular zone may be related with synthesis of 17-hydroxy-pregnenolone, 17-hydroxy-progesterone, dehydroepiandrosterone or androstenedione.
\end{abstract}

Keywords: adrenal cortex, adrenal medulla, CYP, steroidogenic enzymes, wild rodents.

\section{Glândulas adrenais de preás (Galea spixii, Wagler, 1831): aspectos morfológicos e morfométricos}

\section{Resumo}

Considerando a importância fisiológica e a necessidade de melhor conhecimento morfofisiológico das glândulas adrenais, os objetivos do presente estudo foram comparar dados morfométricos entre adrenais direitas e esquerdas de machos e fêmeas; realizar estudos histológicos e microscopia eletrônica de varredura e transmissão revelando a constituição tecidual das glândulas; finalmente, foi realizado estudo imunohistoquímico com objetivo de definir a presença e correto sítio de expressão da citocromo P450c17 nas glândulas adrenais em 18 glândulas adrenais (direita n=9 e esquerda $n=9$ ) de nove Galea spixii adultos (quatro machos e cinco fêmeas). A glândula adrenal direita estava posicionada mais cranialmente que a adrenal esquerda; as dimensões (peso, comprimento e largura) da glândula adrenal direita foram maiores que as da esquerda; não houve diferença entre as medidas corpóreas e das adrenais entre machos e fêmeas; a morfologia das células e diferentes quantidades de gotículas lipídicas podem estar relacionadas a diferentes demandas na produção de hormônios esteroides relacionados a cada zona do córtex adrenal; e, a imunolocalização da citocromo P450 na zona fasciculada e reticular pode estar relacionado com a síntese de 17-hidroxi-pregnenolona, 17-hidroxi-progesterona, dehidroepiandrosterona ou androstenediona.

Palavras-chave: córtex adrenal, medula adrenal, CYP17, enzimas esteroidogênicas, roedores silvestres. 


\section{Introduction}

In mammals, each adrenal gland is composed by two distinct steroidogenic structures: the cortex, whose embryological origin is the mesoderm and the medulla with embryological origin from the neuroectoderm. Each part of adrenal gland has different cell types: cells producing sexual steroid hormones, glucocorticoids and mineralocorticoids are present in the cortex, and chromaffin cells, which are producers of catecholamine and neuropeptides are present in medullar region (Hîncu et al., 2006; Kempná and Flück, 2008; Chang et al., 2011; Parker et al., 2011; Quinn et al., 2013; Qiu et al., 2013).

Some studies have focused on the ultrastructure and morphology of the different cell types present in each layer of the adrenal cortex and medulla during intrauterine development and the immunolocalization of steroidogenic enzymes, especially that responsible for androgens production, as cytochrome P450c17 in species of wild mammals (Quinn et al., 2013). In this sense, the authors have found different sites of androgen production in adrenal glands of different species, as mice (Chang et al., 2011), Rattus norvegicus (van-Weerden et al., 1992; Pignatelli et al., 1998), Balb/c mouse (van-Weerden et al., 1992) and spiny mice (Quinn et al., 2013). Cytochrome P450c17 catalyses two distinct reactions: the $17 \alpha$-hydroxylation of $\mathrm{C}_{21}$ (molecules with 21 atoms of carbon) steroids and the conversion of the $17 \alpha$-hydroxylated $\mathrm{C}_{21}$ steroids to $\mathrm{C}_{19}$ (molecules with 19 atoms of carbon) steroids.

Studies about cytochrome P450 enzymes in adrenal glands have been useful for other researches reporting the relationship of adrenal hormones with several diseases (Hîncu et al., 2006; Kempná and Fluck, 2008; Miller, 2009; Laborie et al., 2011; Parker et al., 2011), genetic disorders (Mapes et al., 1999) and its relationship with the mechanisms of birth in several mammals (Conley and Assis-Neto, 2008; Miller, 2009). Studies related to the hypothalamic-pituitary-adrenal (Parker et al., 2011), androgenization of mammals female due the large production of androgen hormones by the adrenal (Yalcinkaya et al., 1993; Ostner et al., 2003) and adrenal changes related to photoperiod were also found (Ribes et al., 1999; Schibler and Brown, 2005).

Spix's yellow-toothed (SYT) cavy (Galea spixii, Wagler, 1831), the experimental model utilized in present research (Larcher, 1981; Oliveira et al., 2012) belongs to family Caviidae and subfamily Caviinae (Zappes et al., 2014), occurs in a wide variety of open habitats and can reproduce throughout year because females can support pregnancy even devoid ideal feeding conditions (Larcher, 1981). It is found in semiarid to arid climate region of Brazilian Northeastern (Oliveira et al., 2008) where it is constantly used as an alternative source of protein for inhabitants of this region. For this reason, it is bred in captivity to provide alternative food, preserve the species and to development of a new experimental model (Santos et al., 2015).

In our previous studies, polyestrous cycles of females lasting 14-19 days (Santos et al., 2015) with development of vaginal closure membrane (Santos et al., 2014a) were found. In other study, cytochrome enzymes P450c17 and P450 aromatase were found in vaginal tissue throughout estrous cycle suggesting a local production of androgen and estrogen hormones (Santos et al., 2014b) in agreement with several studies that have shown a wide variety of different production sites of steroid hormones in different mammalian species (Conley and Hinshelwood, 2001; Conley et al., 2004).

Molecular studies have been useful for more precise phylogenetic classification between members of Caviidae family (Zappes et al., 2014), in this sense, P450c17 from different species have different enzymatic activities in different species of mammals (Shet et al., 2007).

The aims of present study were compare the morphometric data between left and right adrenal of males and females; perform a histological, scanning and transmission electron microscopy study showing tissue constitution of glands; finally, in order to define the presence and correct site of the cytochrome P450c17 expression in adrenal glands, immunohistochemical study of this enzyme was performed.

\section{Material and Methods}

\subsection{Animals}

Eighteen adrenal glands (right $\mathrm{n}=9$ and left $\mathrm{n}=9$ ) were used from nine healthy SYT cavies (five no pregnant females and four males) adults (from 6 to 12 months old), prevenient of the Center for Wild Animals Multiplication at Federal Rural University of the Semi-Arid, in the Mossoro RN Brazil. The breeding Center was authorized by Brazilian Institute of Environment and Renewable Resources (IBAMA, 2028236/2008). The present research had permission of the Bioethics Committee of the School of Veterinary Medicine and Animal Science of the University of Sao Paulo, SP, Brazil (protocol 2400/2011).

Animals were bred in pens of $2.5 \mathrm{~m}^{2}$, surrounded with wire mesh, with sand floors and roof of asbestos. The animals were fed with fruits, grasses, corn, rabbit feed and water. No stress induction was performed. The animals were anesthetized with xylazine $(4 \mathrm{mg} / \mathrm{kg} / \mathrm{IM})$ and ketamine $(60 \mathrm{mg} / \mathrm{kg} / \mathrm{IM})$ and euthanized by administration of thiopental sodium $(2.5 \% 60 \mathrm{mg} / \mathrm{Kg} / \mathrm{EV})$ through the intracardiac route in August-October 2011.

\subsection{Macroscopic and morphometric analysis}

The animals were weighed on a precision balance and measured by digital caliper. Then, they were positioned in dorsal decubitus and dissected by abdominal access using scissors, forceps and bistoury. Topographic localization and association with other abdominal organs, analysis of coloration and analysis of format comparing left and right adrenals were performed and documented by Olympus SP $810 \mathrm{UZ} 14 \mathrm{mp}$. Then, the adrenal glands (left and right) from males and females were weighed on a precision balance. The weight, length and width were analyzed and placed in a table in order to compare male and females body measurements and left and right adrenal differences. 
The analysis of variance using the GraphPad InStat program to obtain the mean and standard deviation was performed. Cramer-von Mises test for normality checked homoscedasticity between the variables; Tukey comparison average test provided morphometric rates. Biometrics variables were unstable $(\mathrm{CV} \leq 15 \%)$, at significance concentration $\mathrm{p}<0.05$ (Viana et al., 2012).

\subsection{Light Microscopy (LM)}

The adrenals were cut at half in the sagittal plane, dividing the organ into two hemi-adrenals, then hemi-adrenals were fixed in 10\% formaldehyde solution and dehydrated in a series of ethanol in increasing concentrations (from 50 to $100 \%$ ) and diaphanized by xylene for later inclusion in paraffin. Then, slices with $5 \mu \mathrm{m}$ thickness were obtained by Leica RM2165 microtome and stained with H.E. (hematoxylin/eosin). The microscopic photodocumentation using a light microscope Olympus BX61VS was performed.

\subsection{Scanning Electron Microscopy (SEM)}

For analysis of superficial differences between different zones of cortex and medulla, the remaining hemi-adrenals were cut at half in transversal plane and the halves of each hemi-adrenal were fixed in $2.5 \%$ glutaraldehyde followed by washing with $0.1 \mathrm{M}$ phosphate buffer at $\mathrm{pH} 7.4$ and post-fixation in osmium tetroxide $1 \%$. Subsequently, dehydration by ethyl alcohol at 50\%,70\%, $90 \%$ and $100 \%$ and finally at the critical point Balzers CPD 020 was carried. The fragments of tissues were fixed in metal supports (stubs) and then these were coated with gold "sputtering" Emitech K550. For analysis, Electron Microscope Zeiss LEO 435VP was used.

\subsection{Transmission Electron Microscopy (TEM)}

For analysis of interior of cells at different zones of cortex and medulla, other halves of hemi-adrenal were fixed in $2.5 \%$ glutaraldehyde, washed in $0.1 \mathrm{M}$ phosphate buffer and post-fixed in osmium tetroxide $1 \%$. Then, the samples were dehydrated by ethanol in increasing concentrations (from 50 to $100 \%$ ), in propylene oxide and resin. The mixture was replaced by pure resin and placed in molds. The ultrathin sections were collected on copper screens and contrasted with uranyl acetate solution at $2 \%$ and $0.5 \%$ lead citrate. The samples were analyzed by transmission electron microscopy MORGAGNI 268d.

\subsection{Immunohistochemistry (cytochrome P450c17)}

To verify the site of production of sex steroid hormones by immunohistochemistry, hemi-adrenals (right and left $\mathrm{n}=3$ ) and testicle as positive control were fixed in $4 \%$ buffered paraformaldehyde solution, dehydrated in a series of ethanol in increasing concentrations (from 50\% to $100 \%$ ) and diaphanized by xylene, for later inclusion in paraffin blocks. Sections of paraffin blocks with $3 \mu \mathrm{m}$ by Leica RM2165 microtome were obtained.

Then, the samples were kept for 3 hours at $70{ }^{\circ} \mathrm{C}$, diaphanized in xylene and rehydrated in ethanol, followed by distilled $\mathrm{H}_{2} \mathrm{O}$. They were immersed in citrate buffer and warmed at $90^{\circ} \mathrm{C}$ in a microwave. Blocking of endogenous peroxidase activity using $3 \% \mathrm{H}_{2} \mathrm{O}_{2}$ was performed and Normal Horse Serum (Vector Labs, Burlingame, CA, USA) for protein-block was added. Then, the samples were incubated with primary antibodies anti-mouse/rabbit cytochrome P450c17 (donated by Prof. Dr. Alan J. Conley, UC Davis, California, USA) for 16 hours. For controls tissue, the primary antibody was discarded and phosphate buffer was added (Assis-Neto et al., 2010).

After incubation with primary antibody, the conjugation with anti-mouse/rabbit secondary antibody Immpress ${ }^{\circledR}$ Universal Kit (Vector Labs, Burlingame, CA, USA) was performed. Then, the amplifying solution Vectstain ${ }^{\circledR} \mathrm{ABC}$ peroxidase kit (Vector Labs, Burlingame, CA, USA) was added. For the development IMMPACT ${ }^{\circledast}$ DAB (Vector Labs, Burlingame, CA, USA) was added. Finally, samples were counterstained with hematoxylin and light microscope Olympus BX61VS for photodocumentation was used.

\section{Results}

\subsection{Topographic and macroscopic analysis}

Both adrenal glands (from right and left antimere) of SYT cavies were located in the abdominal cavity; craniomedially associated with the right and left cranial pole of kidneys, respectively. It was possible to observe that the right adrenal was most cranially positioned, when compared to the left adrenal in both males and females (Figure 1).

The right adrenal was ventrocaudally related to the liver, while the left adrenal was ventrocaudally related with the major curvature of stomach. The right adrenal had more irregular shape than left adrenal. While the right adrenal had pyramidal shape in majority of cases, the left adrenal had elongated shape and more homogeneous formats. Externally, the color of glands ranged from red to light brown (Figure 2).

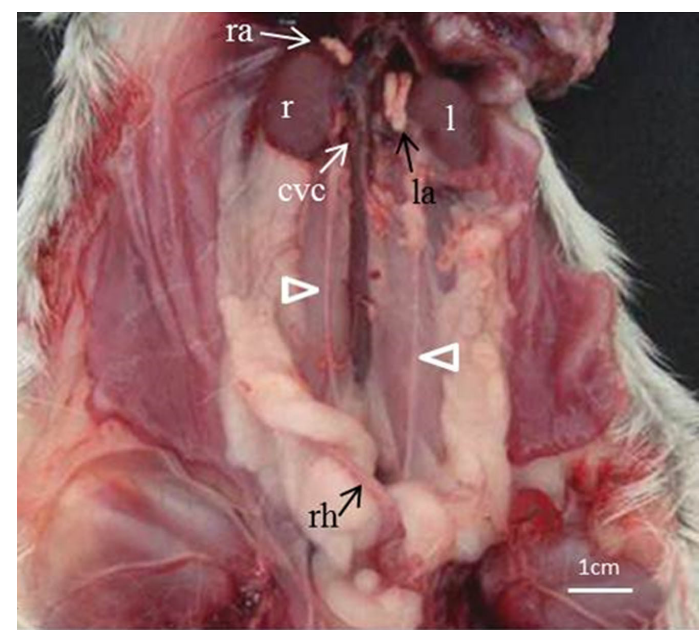

Figure 1. Photography of the topographic position of right and left adrenal glands of the SYT cavies in the abdominal cavity. Adrenal glands: right (ra) and left (la); left kidney (1); right kidney (r); caudal vena cava (cvc); ureters (arrowhead); right uterine horn (rh). Bar: $1 \mathrm{~cm}$. 
After the sagittal incision in the adrenal, dividing the organ in hemi-adrenals, three distinct layers were noted in the cortex and a medullar region in both adrenal glands (right and left). The inner layer of cortex was the reticular zone, associated with medullar region; fasciculate zone was in the middle; and, the outer layer of cortex was glomerular zone, which was associated with the capsule of organ. Medullar region was in the center of organ. Glomerular and reticular zones had light yellow coloration and fasciculate zone had orange coloration at the cortex. Medulla had red coloration (Figure 3).

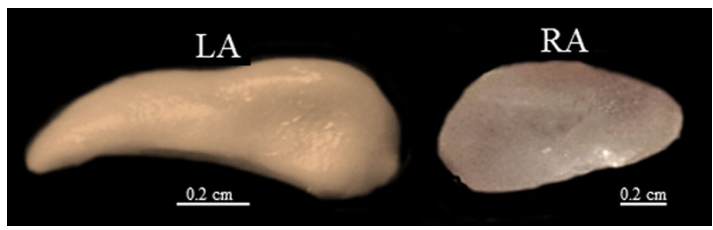

Figure 2. Photography of different shapes of right (RA) and left (LA) adrenal glands of the SYT cavies. Bars: $0.2 \mathrm{~cm}$.

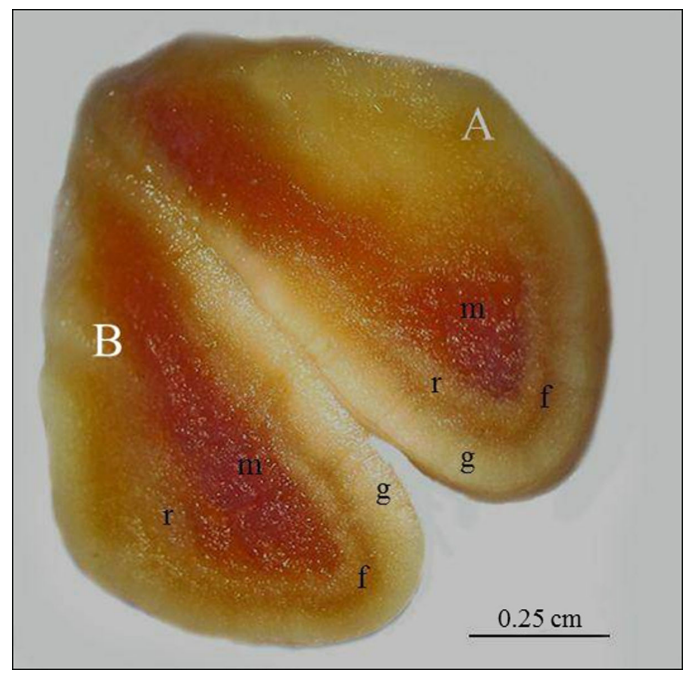

Figure 3. Adrenal gland of SYT cavies divided into two hemi-adrenals (A and B) by median sagittal incision, showing the glomerular zone (g), fasciculate zone (f), reticular zone of cortex region (r); and, medullar region $(\mathrm{m})$. Bar: $0.25 \mathrm{~cm}$.
When compared male and female body measurements (Table 1) and male and female adrenal measurements (weight, length and width) no differences were found with $\mathrm{p}<0.05$ (Tukey test) (Table 2). Significant statistical differences between right (largest) and left adrenal (minor) for both male and female were found.

\subsection{Light Microscopy (LM)}

By light microscopy, the left and right adrenals were divided in both males and females into two portions: cortex and medulla. The cells of the cortex are concentrically arranged in three distinct zones: glomerular, fasciculate, and reticular, with differentiation of these regions based on their cellular arrangement. The glomerular zone was located just under the capsule (composed by connective tissue), which surrounds the organ. The main characteristic of the glomerular zone was the presence of oval cells arranged into arc-like groups. The largest zone was the fasciculate, characterized by long cords of cells. The third zone was the reticular, which contain a plot of irregular cellular cords, anastomosed, and with random arrangement. Below of the reticular zone, centrally in the organ, the medullar region comprising large chromaffin cells and numerous blood vessels was found (Figure 4).

\subsection{Scanning Electron Microscopy (SEM)}

By SEM, capsule of organ and the difference between the layers of the cortex, especially at the junction between the glomerular and fasciculate zone and between the junctions from reticular zone to medullar region was noted. In the medullar region a lot of blood vessels were found (Figure 5).

\subsection{Transmission Electron Microscopy (TEM)}

For analysis by TEM, a qualitative study was conducted, mainly based on the distribution of lipid droplets and the formatting of the cellular nuclei of different cortical zones and medullar region from right and left adrenal.

The cortex was composed by three zones. The glomerular zone had cells arranged in tubular-shaped structure. These tubes were separated by connective tissue and had little amount of lipid vesicles in relationship to the fasciculate and reticular zone.

The fasciculate zone had large cells with central nucleus and visible nucleolus, large amount of mitochondria and cytoplasm filled with enormous amount of lipid vesicles,

Table 1. Weight and crown-rump measurements of male and female G. spixii.

\begin{tabular}{|c|c|c|c|c|}
\hline \multicolumn{5}{|c|}{ Animal Measurements } \\
\hline \multirow{2}{*}{ animal } & \multicolumn{2}{|c|}{ weight (g) } & \multicolumn{2}{|c|}{ crown-rump (cm) } \\
\hline & male & Female & male & female \\
\hline 1 & 355.00 & 441.00 & 25.00 & 27.00 \\
\hline 2 & 309.10 & 305.05 & 21.50 & 23.00 \\
\hline 3 & 284.15 & 325.10 & 23.50 & 23.10 \\
\hline 4 & 415.30 & 297.10 & 25.00 & 24.05 \\
\hline 5 & - & 309.05 & - & 21.07 \\
\hline mean+SD* & $340.89 \pm 57.64 a$ & $335.46 \pm 59.87 a$ & $23.75 \pm 1.66 \mathrm{a}$ & $23.64 \pm 2.17 a$ \\
\hline
\end{tabular}

\footnotetext{
*Means with the same letters in the same line indicate that there was no statistical difference $(\mathrm{p}<0.05)$ for Tukey test.
} 
Table 2. Weight, length and width measurements of left and right adrenal of male and female G. spixii.

\begin{tabular}{|c|c|c|c|c|}
\hline \multicolumn{5}{|c|}{ Adrenal measurements } \\
\hline \multirow{3}{*}{ animal } & \multicolumn{3}{|c|}{ weight $(\mathrm{g})$} & \\
\hline & \multicolumn{2}{|c|}{ Left } & \multicolumn{2}{|c|}{ Right } \\
\hline & male & Female & male & Female \\
\hline 1 & 0.10 & 0.15 & 0.08 & 0.11 \\
\hline 2 & 0.09 & 0.09 & 0.05 & 0.05 \\
\hline 3 & 0.10 & 0.07 & 0.06 & 0.07 \\
\hline 4 & 0.10 & 0.06 & 0.08 & 0.08 \\
\hline 5 & - & 0.08 & - & 0.04 \\
\hline mean+SD* & $0.10 \pm 0.01 \mathrm{a}$ & $0.09 \pm 0.04 a$ & $0.07 \pm 0.01 \mathrm{a}$ & $0.07 \pm 0.03 a$ \\
\hline \multicolumn{5}{|c|}{ length (cm) } \\
\hline \multirow{2}{*}{ animal } & \multicolumn{2}{|c|}{ Left } & \multicolumn{2}{|c|}{ Right } \\
\hline & Male & Female & male & Female \\
\hline 1 & 1.07 & 1.05 & 0.94 & 0.70 \\
\hline 2 & 1.16 & 1.23 & 1.01 & 0.47 \\
\hline 3 & 1.16 & 1.21 & 1.00 & 0.49 \\
\hline 4 & 1.30 & 1.10 & 1.00 & 0.54 \\
\hline 5 & - & 1.27 & - & 0.52 \\
\hline mean+SD* & $1.17 \pm 0.10 a$ & $1.17 \pm 0.09 a$ & $0.99 \pm 0.03 a$ & $0.54 \pm 0.09 a$ \\
\hline \multicolumn{5}{|c|}{ width (cm) } \\
\hline \multirow{2}{*}{ animal } & \multicolumn{2}{|c|}{ Left } & \multicolumn{2}{|c|}{ Right } \\
\hline & Male & Female & male & Female \\
\hline 1 & 0.61 & 0.70 & 0.45 & 0.45 \\
\hline 2 & 0.40 & 0.47 & 0.60 & 0.42 \\
\hline 3 & 0.56 & 0.49 & 0.44 & 0.42 \\
\hline 4 & 0.53 & 0.54 & 0.55 & 0.50 \\
\hline 5 & - & 0.52 & - & 0.48 \\
\hline mean+SD* & $0.53 \pm 0.09 a$ & $0.54 \pm 0.09 a$ & $0.51 \pm 0.08 a$ & $0.45 \pm 0.04 a$ \\
\hline
\end{tabular}

*Means with the same letters in the same line indicate that there was no statistical difference $(\mathrm{p}<0.05)$ for Tukey test.

and it was the area where the greatest amount of these vesicles were noted when compared to the other two cortical zones.

In the reticular zone, two cell types were found: the first containing nucleus with fine chromatin and clearly visible nucleolus; the second cell type presented picnotic nuclei and abundant colloidal material. In this region, a large amount of lipid vesicles were found, but in a smaller amount than that found in the fasciculate zone. In the medullar region, blood vessels were possible to visualize, but the presence of lipid vesicles was not found (Figure 6). The results were the same for males and females specimens.

\subsection{Immunohistochemistry (cytochrome P450c17)}

Enzyme cytochrome P450c17 in cells of fasciculate and reticular zones was immunolocalized, but was not found in the glomerular zone and medulla. Leydig cells of testicles used for positive tissue control were immunopositive (Figure 7). No differences between sexes of individuals were noted.

\section{Discussion}

The adrenal glands found in SYT cavies follow the topographic localization described in wild rodents as Lagostomus maximus (Ribes et al., 1999), Myocastor coypus (Machado et al., 2002; Culau et al., 2008), Dasyprocta agouti (Neves et al., 2007), Cavia porcellus (Cooper and Schiller, 1975), domestic animals as dogs, cats and horses (Reece, 2005) besides the humans (Kempná and Fluck, 2008). In all species above described, these glands were cranially positioned to the cranial pole of kidney and medially related to the caudal vena cava. The right adrenal glands of SYT cavies were more cranially located than the left adrenal, as described in Myocastor coypus (Machado et al., 2002). Regarding the format, adrenal glands with very irregular shapes when comparing the right and left adrenal glands were found. The left adrenal had elongated shape and right adrenal had conical or pyramidal shape, as described in Cavia porcellus (Cooper and Schiller, 1975), Lagostamus maximus, (Ribes et al., 

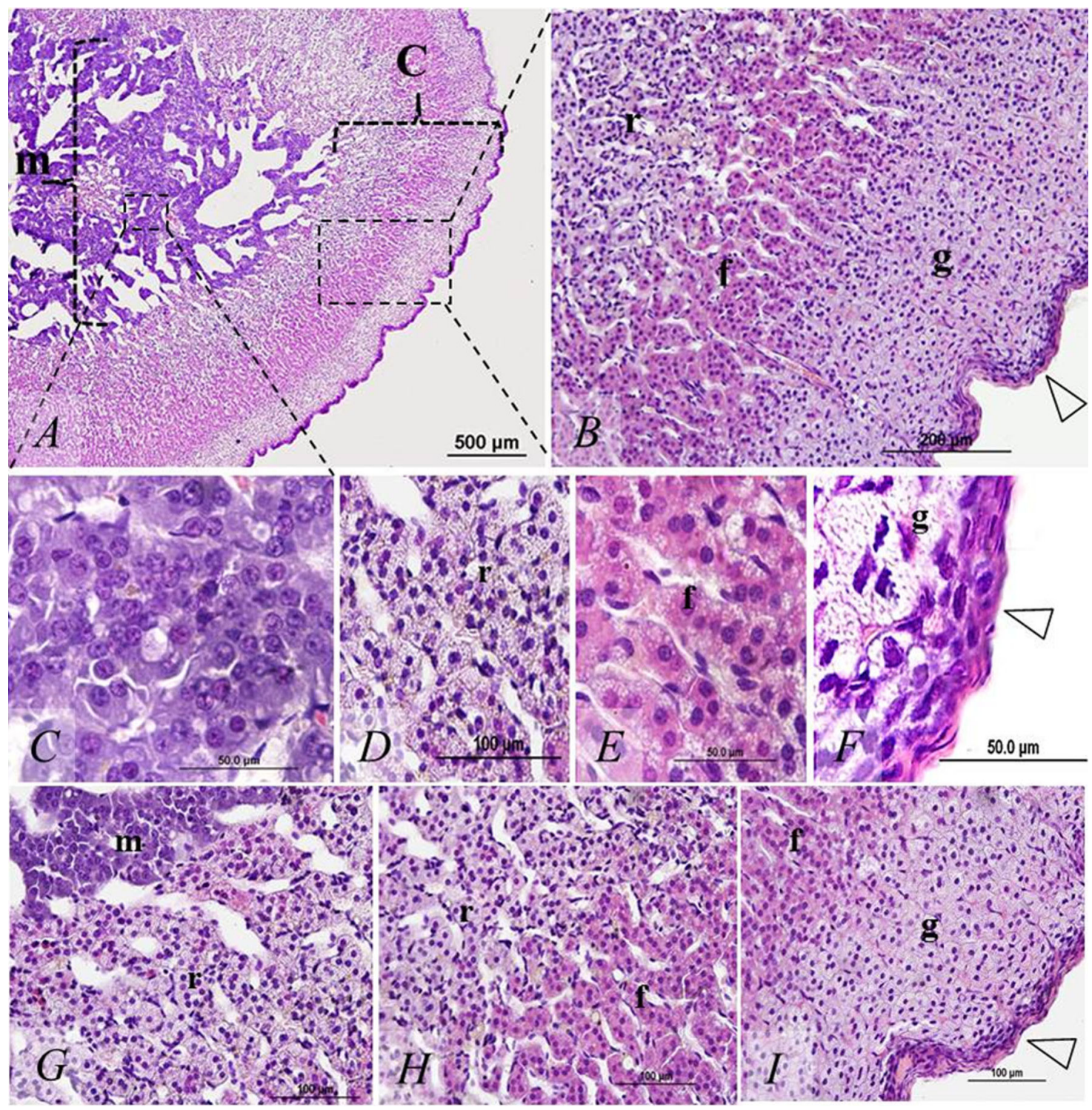

Figure 4. Photography of the adrenal glands of SYT cavies by light microscopy. A: medulla (m) and cortex (c). Bar: 500 $\mu \mathrm{m}$,

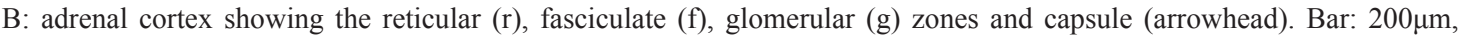
$\mathrm{C}$ : cells from adrenal medulla in higher magnifications. Bar: $50 \mu \mathrm{m}, \mathrm{D}$ : cells from reticular zone in higher magnifications (r). Bar $100 \mu \mathrm{m}$, E: cells from fasciculate zone in higher magnifications (f). Bar: $50 \mu \mathrm{m}$; F: cells from glomerular zone in

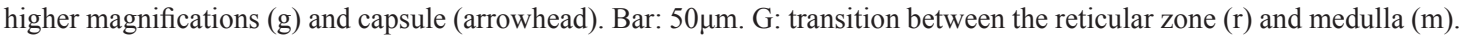
Bar: $100 \mu \mathrm{m} . \mathrm{H}$ : transition between fasciculate and reticular zones (r). Bar: $100 \mu \mathrm{m}$, I: transition between glomerular $(\mathrm{g})$ and fasciculate zones (f) and capsule (arrowhead). H.E. Bar: $100 \mu \mathrm{m}$.

1999) and Myocastor coypus (Machado et al., 2002). Statistical differences were found between right (larger) and left (minor) adrenal dimensions (weight, length and width). When compared male and female body measurements or adrenal dimensions no differences were found.

Microscopically, distinct regions within the adrenal glands were observed: the inner region was the medullar and the outer region was the cortex. The latter was divided into three zones: the outer was glomerular, which was associated with the capsule of organ, the fasciculate was in the middle and reticular was the inner zone of cortex, which was associated with medullar region, as described in other mammals (Kempná and Flück, 2008), including dogs, cats, horses (Reece, 2005) and rodents as Lagostamus maximus (Ribes et al., 1999). During development, rat presents intermediate zone, called undifferentiated zone, located between fasciculate and glomerular zone (Chang et al., 2011). Although no microscopic differences between different areas of the cortex when compared right and left adrenal gland of male and female SYT cavies were found 


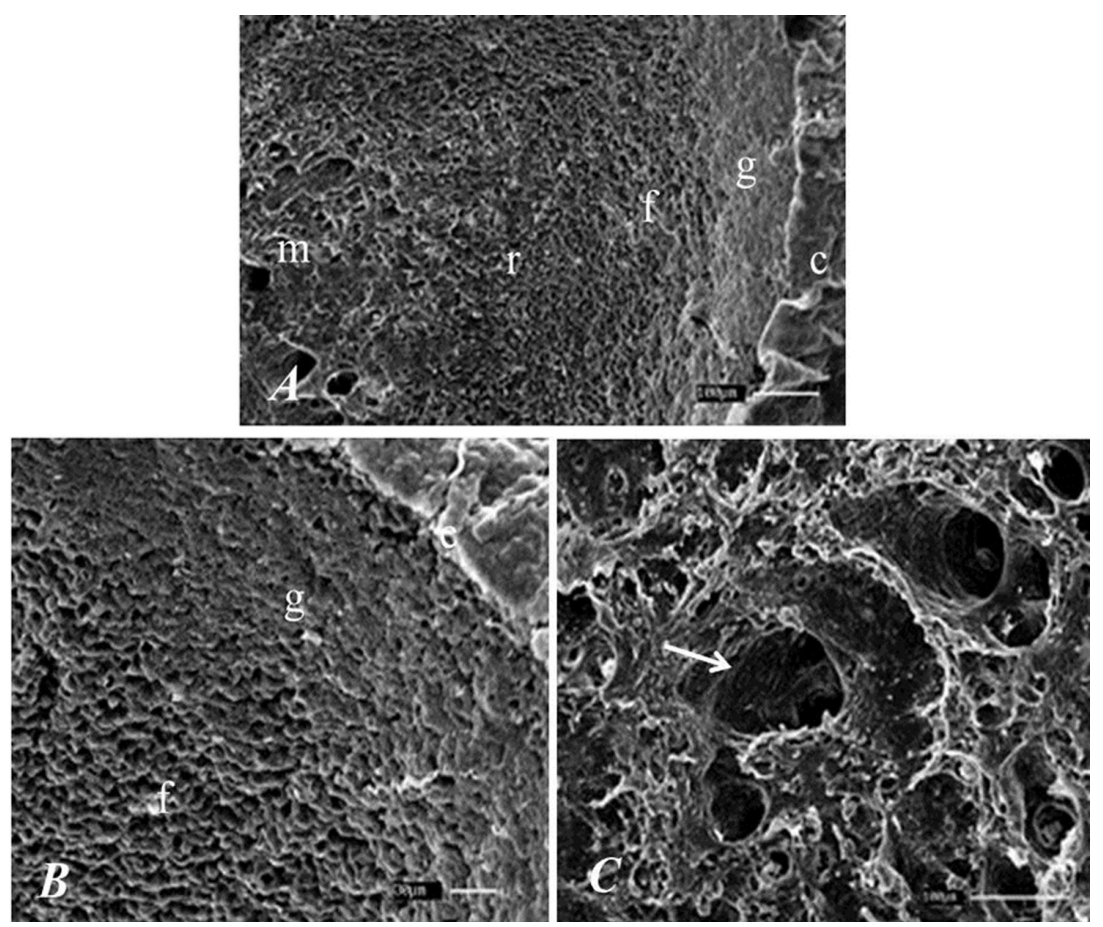

Figure 5. Photography of the adrenal gland of the SYT cavies. A: capsule (c), glomerular (g), fasciculate (f) reticular (r) zones and medulla (m). Bar: $100 \mu \mathrm{m}$. B: glomerular (g) and fasciculate zone (f). Bar $30 \mu \mathrm{m}$. C: adrenal medulla showing blood vessel (arrow). Bar: $100 \mu \mathrm{m}$.
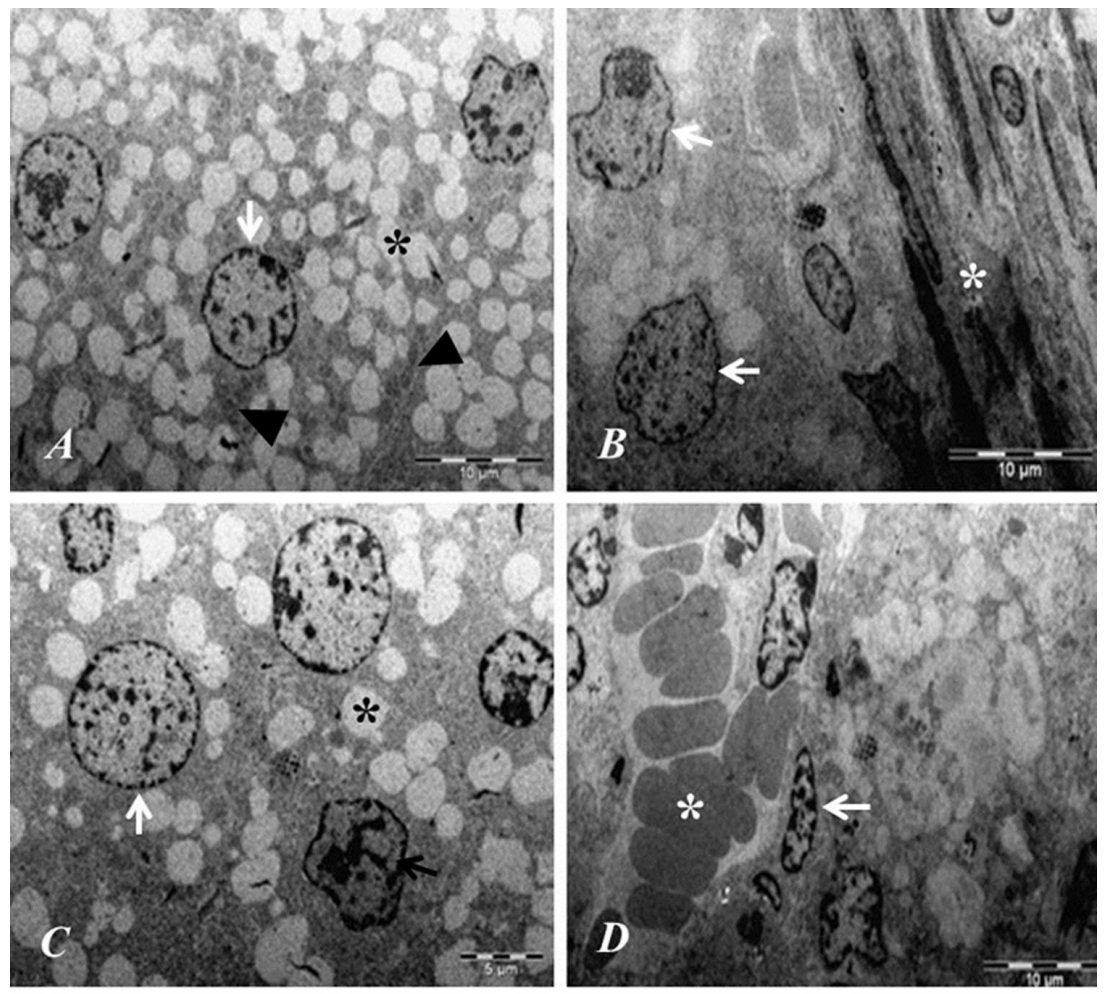

Figure 6. Photography of the adrenal glands of the SYT cavies. A: cellular nucleus (arrow), mitochondria (arrowhead) and lipid droplets $(*)$ of fasciculate zone. Bar: $10 \mu \mathrm{m}$. B: approximated nucleus (arrow) and connective tissue $(*)$ of glomerular zone. Bar: $10 \mu \mathrm{m}$. C: cell type with picnotic nuclei (black arrow) and cell type with little dense chromatin (white arrow) of reticular zone. Bar: $5 \mu \mathrm{m}$. D: granular chromaffin cells (arrow) and blood vessels $(*)$ of medullar region. Bar: $10 \mu \mathrm{m}$. 


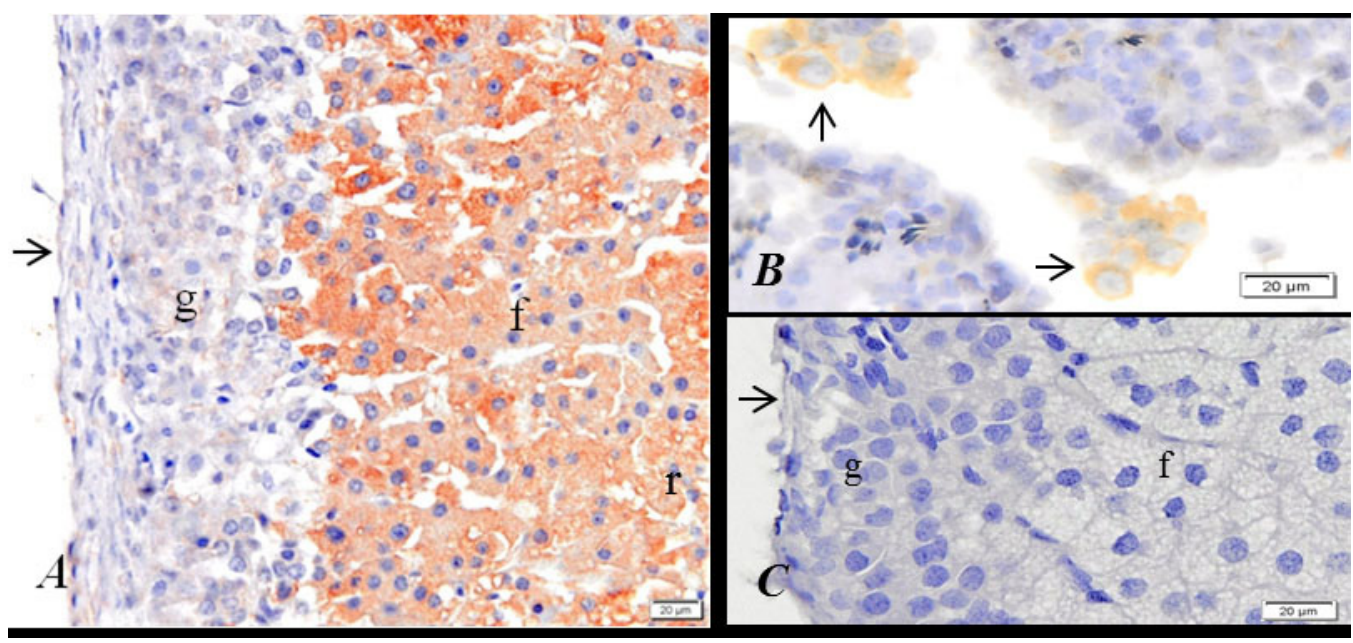

Figure 7. Immunolocalization of cytochrome P450c17 in adrenal glands of the SYT cavies. A: capsule (arrow), glomerular $(\mathrm{g})$, fasciculate (f) and reticular (r) zones. Note strong immunostaining (brown) in the fasciculate zone. B: Positive control showing immunostaining at Leydig cells (arrows) of testicles. C: capsule (arrow) glomerular (g) and fasciculate zones (f) of the negative control sample. Bars: $20 \mu \mathrm{m}$.

in present study, further studies might reveal microscopic differences between right and left adrenal gland or between adrenal from male and female.

Regarding the different zones of the adrenal cortex in SYT cavies: the glomerular zone had presence of groups of ovoid cells, adhered with each other and with reduced intracellular spaces, similar that found in rats (Chang et al., 2011) and Gerbilus tarabuli (Saadi and Lebaili, 2012); the fasciculate zone was characterized by long cords of vacuolated cells, as found in rats (Chang et al., 2011); the reticular zone had in its parenchyma, a plot of irregular cords of cells, anastomosed, and, with random arrangement. Two types of cells were found: one with fine chromatin and visible nucleolus and other type with picnotic nucleus, which is related to cellular apoptosis, similar that found in Lagostamus maximus (Ribes et al., 1999). Finally, in medullar region, large chromaffin cells and numerous blood vessels, similar to that described in Cavia porcellus were found (Kmieć and Kaczmarczyk, 2004).

In Gerbillus tarabili (Saadi and Lebaili, 2012) undergoing diet rich in water, the cells of glomerular zone were arranged in clusters surrounded by a network of fenestrated capillaries with rounded shape and variable size. Their nuclei varied in size and had one nucleolus. In this study, the authors observed mitochondria filling the cytoplasm, very close to lipid droplets. In our study, using animals bred in captivity, these characteristics were observed in the cells of the fasciculate zone.

Saadi and Lebaili (2012) suggest that changes in the cortex are a reflex of the anatomical and physiological adaptive capacity of the adrenal gland to stress factors. Similar features of the fasciculate zone of SYT cavies were found in Lagostomus maximus (Ribes et al., 1999). Furthermore, Hîncu et al. (2006) while studying Cavia porcellus said that the fasciculate zone is positively associated with increasing or decreasing of its area, in according to the dynamics of the stress response. Another study with Rattus norvegicus pinealectomized showed that the absence of the pineal gland causes weight gain in adrenal gland and cellular hypertrophy of the fasciculate zone (Lima et al., 2002). We suggest further histometric studies in SYT cavies taking into account the thickness of different cortical zones comparing free living and bred in captivity animals in order to demonstrate morphological adjustments related to different levels of stress.

The different proportions of lipid droplets in different cortical zones found in our study could be related to production of steroid hormones, which are derived from cholesterol (Shinzawa et al., 1988; Schibler and Brown, 2005; Chang et al., 2011). On the other hand the absence of lipid droplets in the medullar region indicates a non-production of steroid hormones, but catecholamine and neuropeptides production, as described by Qiu et al. (2013). Similar to that found in SYT cavies, Kmieć and Kaczmarczyk (2004) studied the cellular composition of medullar region of adrenal gland in Cavia porcellus and observed the granular appearance of vesicles present in chromaffin cells.

Regarding the production of sex steroid hormones in the fasciculate and reticular zone of SYT cavies by presence of cytochrome P450c17, different results in humans and primates, in which the site of production of androgen hormones is the reticular zone were described (Chang et al., 2011). In rats, the production site is the glomerular and fasciculate zone by the expression of the enzyme 3-beta-HSD during ontogeny of the organ (Pignatelli et al., 1998), which is related to production of progesterone, 17-hidroxy-progesterone, testosterone and androstenedione (Miller, 2009). In rats and Balb/c mice, the cytochrome P450c17 is absent in adrenal and 
therefore the authors suggest that this organ does not contribute to production of androgens (van-Weerden et al., 1992). However, in C. porcellus, the cytochrome P450c17 enzyme is predominantly distributed in the fasciculate zone, but is also found in lower quantities in the reticular zone (Shinzawa et al., 1988), as also found in Spiny mouse (Quinn et al., 2013). In the absence of P450c17 in the glomerular zone C21-deoxy-steroids are produced, leading to mineralocorticoids aldosterone. In the presence of the 17 $\alpha$-hydroxylase but not the 17, 20 lyase activity of $\mathrm{P} 450 \mathrm{c} 17$ in the fasciculate zone, C21, 17-hydroxy-steroids are produced, leading to the glucocorticoid production (Miller, 2009).

Further studies of adrenal glands of SYT cavies are required in order to describe which hormones are produced by the enzyme cytochrome P450c17, since this enzyme participates in the synthesis of 17-hydroxy-pregnenolone (pregnenolone-derived), 17-hydroxy-progesterone (progesterone-derived) and the androgen hormones dehydroepiandrosterone (DHEA) and androstenedione (Praporski et al., 2009), even though the androgen hormone commonly produced in the adrenal with physiological importance is DHEA (Quinn et al., 2013), but there are some differences between different species of mammals (Conley et al., 2004).

The present research may be useful, because researches have shown that some mammals provide excellent models for human adrenal androgen synthesis and secretion and each species have its own particular strengths. It remains only that these must be clearly defined anatomically, biochemically, and otherwise. Variations offer opportunities available to understand the most important developmental and regulatory triggers (Conley et al., 2004).

\section{Conclusion}

Right adrenal was more cranially positioned than left adrenal; dimensions of right adrenal was larger than left adrenal for both male and female; when compared male and female body and adrenal measurements no differences were found; the morphology of cells and different amounts of lipid droplets may be related to the different demands of steroid hormones production, related to each zone of the adrenal cortex; and, the cytochrome P450c17 immunolocalization in fasciculate and reticular zone may be related with synthesis of 17-hydroxy-pregnenolone, 17-hydroxy-progesterone, dehydroepiandrosterone or androstenedione.

The morphology of the adrenal glands of SYT cavies were similar that found in another rodents compared in present research, but the expression of cytochrome P450c17 still needs further studies, because differences were found between different species of rodents.

\section{Acknowledgements}

To Federal Rural University of Semi-Arid for supplying the animals used in this study; to IBAMA (Brazilian Institute of Environment and Renewable Resources) for license for captive breeding of the same; to FAPESP (Fundação de Amparo à Pesquisa do Estado de São Paulo) for financial support; and, to professor Dr. Alan James Conley at University of California, Davis, USA for donating of primary antibody.

\section{References}

ASSIS-NETO, A.C., BALL, B.A., BROWNE, P. and CONLEY, A.J., 2010. Cellular localization of androgen synthesis in equine granulosa-theca cell tumors: immunohistochemical expression of 17 alfa-hydroxylase/17,20-lyase cytochrome P450. Theriogenology, vol. 74, no. 3, pp. 393-401. http://dx.doi.org/10.1016/j. theriogenology.2010.02.022. PMid:20416939.

CHANG, S.P., MULLINS, J.J., MORLEY, S.D. and WEST, J.D., 2011. Transition from organogenesis to stem cell maintenance in the mouse adrenal cortex. Organogenesis, vol. 7, no. 4, pp. $267-$ 280. http://dx.doi.org/10.4161/org.7.4.18060. PMid:22198434.

CONLEY, A. and HINSHELWOOD, M., 2001. Mammalian aromatases. Reproduction, vol. 121, no. 5, pp. 685-695. http:// dx.doi.org/10.1530/rep.0.1210685. PMid:11427156.

CONLEY, A.J. and ASSIS-NETO, A.C., 2008. The ontogeny of fetal adrenal steroidogenesis as a prerequisite for the initiation of parturition. Experimental and Clinical Endocrinology \& Diabetes, vol. 116, no. 7, pp. 385-392. http://dx.doi.org/10.1055/s-2008-1076713. PMid:18523926.

CONLEY, A.J., PATTISON, J.C. and BIRD, M., 2004 Variations in adrenal androgen production among (nonhuman) primates. Seminars in Reproductive Medicine, vol. 22, no. 4, pp. 311-326. http://dx.doi.org/10.1055/s-2004-861548. PMid:15635499.

COOPER, G. and SCHILLER, A.L., 1975. Anatomy of the guinea pig. Cambridge: Harvard University Press. 417 p.

CULAU, P.O.V., AZAMBUJA, R.C. and CAMPOS, R., 2008. Ramos colaterais viscerais da artéria aorta abdominal em Myocastor coypus nutria. Acta Scientiae Veterinariae, vol. 36, no. 3 , pp. $241-247$

HÎNCU, M., PETCU, L.C., MEHEDINȚI, R. and MEHEDINŢI, T., 2006. Correlated histological and morphometric study of kidney and adrenal gland from Guinea pig exposed to hyperbarichyperoxic environment. Romanian Journal of Morphology and Embryology, vol. 47, no. 1, pp. 47-51. PMid:16838057.

KEMPNÁ, P. and FLÜCK, C.E., 2008. Adrenal gland development and defects. Best Practice \& Research: Clinical Endocrinology \& Metabolism, vol. 22, no. 1, pp. 77-93. http://dx.doi.org/10.1016/j. beem.2007.07.008. PMid:18279781.

KMIEĆ, B.L. and KACZMARCZYK, D., 2004. The cellular composition of the adrenal medulla of sexually mature guinea pigs. Folia Morphologica, vol. 63, no. 1, pp. 75-78. PMid:15039905.

LABORIE, C., MOLENDI-COSTE, O., BRETON, C., MONTEL, V., VANDENBULCKE, F., GRUMOLATO, L., ANOUAR, Y. and VIEAU, D., 2011. Maternal perinatal undernutrition has long-Term consequences on morphology, function and gene expression of the adrenal medulla in the adult male rat. Journal of Neuroendocrinology, vol. 23, no. 8, pp. 711-724. http://dx.doi. org/10.1111/j.1365-2826.2011.02159.x. PMid:21564351.

LARCHER, T.E., 1981. The comparative social behaviour of Kerodon rupestris and Galea spixii and the evolution of behaviour in the Caviidae. Bulletin of Carnegie Museum of Natural History, vol. 17 , no. 1 , pp. 1-71. 
LIMA, L.M.B., LIMA, M.A., RITA, C.V.C. and OLIVEIRA, P.F., 2002. Influência da pineal sobre a morfologia do córtex da adrenal. Medicina, vol. 35, no. 1, pp. 36-40. PMid:12474715.

MACHADO, G.V., ROMAGNOLLI, P., SOUZA, J.R., TURQUETI, V.S., ULIANA, S.M. and SILVA, M.H., 2002. Suprimento arterial para as glândulas adrenais no ratão do banhado (Myocastor coypus, Molina, 1782). Archives of Veterinary Science, vol. 7, pp. 9-14.

MAPES, S., CORBIN, C.J., TARANTAL, A. and CONLEY, A.J., 1999. The primate adrenal zona reticularis is defined by expression of cytochrome b5, 17alpha-hydroxylase/17,20-lyase cytochrome $\mathrm{P} 450$ (P450c17) and NADPH-cytochrome P450 reductase (reductase) but not 3beta-hydroxysteroid dehydrogenase/delta5-4 isomerase (3beta-HSD). The Journal of Clinical Endocrinology and Metabolism, vol. 84, no. 9, pp. 3382-3385. http://dx.doi. org/10.1210/jcem.84.9.6105. PMid:10487714.

MILLER, W.L., 2009. Androgen synthesis in adrenarche. Reviews in Endocrine \& Metabolic Disorders, vol. 10, no. 1, pp. 3-17. http://dx.doi.org/10.1007/s11154-008-9102-4. PMid:18821018.

NEVES, W.C., CAVALCANTE-FILHO, M.F., CARVALHO, M.A.M. and MENEZES D.J.A., 2007. Irrigação das glândulas adrenais em cutia dourada (Dasyprocta aguti). Revista da FVZA, vol. 14 , no. 2 , pp. 165-174.

OLIVEIRA, M.F., MESS, A., AMBRÓSIO, C.E., DANTAS, C.A.G., FAVARON, P.O. and MIGLINO, M.A., 2008. Chorioallantoic placentation in Galea Spixii (Rodentia, Caviomorpha, Caviidae). Reproductive Biology and Endocrinology, vol. 6, no. 39, pp. 1-8. http://dx.doi.org/10.1186/1477-7827-6-39. PMid:18771596.

OLIVEIRA, M.F., VALE, A.M., FAVARON, P.O., VASCONCELOS, B.G., OLIVEIRA, G.B., MIGLINO, M.A. and MESS, A., 2012. Development of yolk sac inversion in Galea spixii and Cavia porcellus (Rodentia, Caviidae). Placenta, vol. 33, no. 10, pp. 878-881. http://dx.doi.org/10.1016/j.placenta.2012.06.019. PMid:22809674.

OSTNER, J., HEISTERMANN, M. and KAPPELER, P.M., 2003. Intersexual dominance, masculinized genitals and prenatal steroids: comparative data from lemurid primates. Naturwissenschaften, vol. 90, no. 3, pp. 141-144. PMid:12649757.

PARKER, V.J., MENZIES-JUNIOR, W. and DOUGLAS, A.J., 2011. Differential changes in the hypothalamic-pituitary-adrenal axis and prolactin responses to stress in early pregnant mice. Journal of Neuroendocrinology, vol. 23, no. 11, pp. 1066-1078. http:// dx.doi.org/10.1111/j.1365-2826.2011.02204.x. PMid:21824206.

PIGNATELli, D., PINTO, P., MAGALHÃES, M.M. and MAGALHÃES, M.C., 1998. The development of the adrenal gland zona glomerulosa in the rat: a morphological, immunohistochemical and biochemical study. Molecular and Cellular Endocrinology, vol. 140, no. 1-2, pp. 163-168. http://dx.doi.org/10.1016/S03037207(98)00045-8. PMid:9722185.

PRAPORSKI, S., NG, S.M., NGUYEN, A.D., CORBIN, C.J., MECHLER, A., ZHENG, J., CONLEY, A.J. and MARTIN, L.L., 2009. Organization of citochrome P450 envolved in sex steroids synthesis: protein interactions in lipid membranes. The Journal of Biological Chemistry, vol. 284, no. 48, pp. 33224-33232. http:// dx.doi.org/10.1074/jbc.M109.006064. PMid:19805543.

QIU, S., DU, Y., WANG, L. and HU, C., 2013. Chromaffin cells of the adrenal gland in the beagle dog. Anatomia, Histologia, Embryologia, vol. 42, no. 2, pp. 144-150. http://dx.doi.org/10.1111/ j.1439-0264.2012.01176.x. PMid:22762393.
QUINN, T.A., RATNAYAKE, U., DICKINSON, H., NGUYEN, T.H., MCINTOSH, M., CASTILLO-MELENDEZ, M., CONLEY, A.J. and WALKER, D.W., 2013. Ontogeny of the adrenal gland in the spiny mouse, with particular reference to production of the steroids cortisol and dehydroepiandrosterone. Endocrinology, vol. 154, no. 3, pp. 1190-1201. http://dx.doi.org/10.1210/en.20121953. PMid:23354096.

REECE, W.O., 2005. Functional anatomy and physiology of domestic animals. Baltmore: Lippincott Willians \& Wilkins. 513 p.

RIBES, A.C., MOHAMED, F., DOMINGUEZ, S., DELGADO, M., SCARDAPANE, L., GUZMAN, J. and PIEZZI, R., 1999. Probable effect of photoperiod on seasonal variation in the nuclear volume of the adrenal cortex of viscacha (Lagostomus maximus). Brazilian Journal of Medical and Biological Research, vol. 32, no. 9, pp. 1115-1120. http://dx.doi.org/10.1590/S0100879X1999000900010. PMid:10464388.

SAADI, L. and LEBAILI, N., 2012. Effect of a water-rich diet on adrenal zona glomerulosa in Gerbillus tarabuli. Comptes Rendus Biologies, vol. 335, no. 2, pp. 96-102. http://dx.doi.org/10.1016/j. crvi.2011.12.002. PMid:22325562.

SANTOS, A.C., BERTASSOLI, B.M., VIANA, D.C., VASCONCELOS, B.G., OLIVEIRA, M.F., MIGLINO, M.A. and ASSIS-NETO, A.C., 2014a. The morphology of female genitalia in Galea spixii (Caviidae, Caviinae). Bioscience Journal, vol. 30, no. 6, pp. 1793-1802.

SANTOS, A.C., OLIVEIRA, M., VIANA, D., MIGLINO, A.C. and ASSIS-NETO, A.C., 2014b. Immunolocalization of the cytochrome P450 enzymes: c17, NADPH reductase and aromatase in the vaginal mucosa of the Spix's yellow-toothed cavy (Galea spixii) during the estrous cycle. Placenta, vol. 35, no. 9, pp. A22. http://dx.doi.org/10.1016/j.placenta.2014.06.074.

SANTOS, A.C., VIANA, D.C., BERTASSOLI, B.M., OLIVEIRA, G.B., OLIVEIRA, D.M., BEZERRA, F.V.F., OLIVEIRA, M.F. and ASSIS-NETO, A.C., 2015. Characterization of the estrous cycle in Galea spixii (Wagler, 1831). Pesquisa Veterinária Brasileira, vol. 35, no. 1, pp. 89-94. http://dx.doi.org/10.1590/ S0100-736X2015000100017.

SCHIBLER, U. and BROWN, S.A., 2005. Enlightening the adrenal gland. Cell Metabolism, vol. 2, no. 5, pp. 278-281. http://dx.doi. org/10.1016/j.cmet.2005.10.001. PMid:16271527.

SHET, M.S., FISHER, C.W., TREMBLAY, Y., BELANGER, A., CONLEY, A.J., MASON, J.I. and ESTABROOK, R.W., 2007. Comparison of the $17 \alpha$-hydroxylase/C17,20 lyase activities of porcine, guinea pig and bovine $\mathrm{P} 450 \mathrm{c} 17 \mathrm{using}$ purified recombinant fusion proteins containing P450c17 linked to NADPH-P450 reductase. Drug Metabolism Reviews, vol. 39, no. 2-3, pp. 289-307. http://dx.doi.org/10.1080/03602530701468391. PMid:17786622.

SHINZAWA, K., ISHIBASHI, S., MURAKOSHI, M., WATANABE, K., KOMINAMI, S., KAWAHARA, A. and TAKEMORI, S., 1988. Relationship between zonal distribution of microsomal cytochrome P450s (P450 17-alfa, lyase and P450c21) and steroidogenic activities in Guinea-pig adrenal cortex. The Journal of Endocrinology, vol. 119, no. 2, pp. 191-200. http://dx.doi. org/10.1677/joe.0.1190191. PMid:2848916.

VAN WEERDEN, W.M., BIERINGS, H.G., VAN STEENBRUGGE, G.F., JONG, D.E. and SCHRÖDER, F.H., 1992. Adrenal glands of mouse and rat do not synthesize androgens. Life Sciences, vol. 50, no. 12, pp. 857-861. http://dx.doi.org/10.1016/00243205(92)90204-3. PMid:1312193. 
VIANA, D.C., SANTOS, A.C., OLIVEIRA, S.S., SILVA-JUNIOR, J.R. and CARVALHO, A.E.B., 2012. The study of tests of average comparisons through the analysis of biochemical values of creatine obtained of four zebuine breeds. Revista de Ciências da Vida, vol. 32, no. 2, pp. 17-22.

YALCINKAYA, T.M., SIITERI, P.K., VIGNE, J.L., LICHT, P., PAVGI, S., FRANK, L.G. and GLICKMAN, S.E., 1993. Mechanism for virilization of female spotted hyenas in utero.
Science, vol. 260, no. 5116, pp. 1929-1931. http://dx.doi. org/10.1126/science.8391165. PMid:8391165.

ZAPPES, I.A., PORTELLA, A.S. and LESSA, G.M., 2014. Description of karyotype of Kerodon acrobata, an endemic rodent in Brazilian Cerrado. Brazilian Journal of Biology $=$ Revista Brasileira de Biologia, vol. 74, no. 1, pp. 251-256. http://dx.doi. org/10.1590/1519-6984.23512. PMid:25055111. 